\title{
PAWEŁ ŁAPIŃSKI
}

Uniwersytet Gdański

pawel.lapinski@poczta.onet.pl

\section{PRZEKŁAD TOWARZYSZĄCY. O POZYCJI TŁUMACZA W ŚWIECIE LITERATURY OBRAZKOWEJ DLA NAJMŁODSZYCH}

\section{Abstract}

Accompanying Translation: The Position of Translator in the World of Illustrated Literature for the Youngest Readers

Translating picture books for children seems to pose a whole range of additional challenges that the translator would not necessarily have to deal with when working on fiction literature targeted at the adult reader. The traditional communication model which pictures the translator as a bridge between the author and the reader is here enriched by a new mediator (an adult reading to the child) and a parallel message (the visual content linked closely to the text).

The article is intended to detail some of the main aspects specific to translation of this type of literature. The corpus of examples is composed of French-language picture books for the youngest readers released recently in Poland.

Examples of translation excerpted from the corpus have been confronted with the visual content of the translated books to examine to what extent, in what situations and how exactly it may support the translator's work or make it more complicated.

The analysis has shown that the main challenges which the translators have to face in such a situation can generally be divided into two groups. The first one contains problems relevant to all literary translations and resulting naturally from grammatical, syntactic or idiomatic differences between the French and Polish languages, which may be further complicated by the visual content accompanying the text. The second group consists of issues specific to illustrated literature that are connected, among others, to the visual literacy of the translator and the technical aspects of the publishing process, such as potential interference in the visual content of the original work.

The author proposes to define the specific conditions of the translator's work with the term "accompanying translation", which is intended to emphasize not only the indelible 
presence of the visual content accompanying the translator at work, but also the collective character of that activity.

Key words: picture book, literary translation, children's literature, visual literacy, accompanying translation.

Słowa klucze: książka obrazkowa, przekład literacki, literatura dziecięca, alfabetyzm wizualny, przekład towarzyszący.

\section{Wstęp}

Dzieciom należy dawać wyłącznie to, co najlepsze. Taką ponoć ideą kierował się Pierre-Jules Hetzel, dziewiętnastowieczny francuski wydawca, który wylansował między innymi powieści Jules'a Verne’a (Skibińska 2008: 231). Zasada ta niekoniecznie przyświecała działalności polskich wydawnictw po otwarciu rynku w latach 90., kiedy to sektor książki dziecięcej został zalany przez mało wyrafinowany, najczęściej anglosaski produkt (Mazepa-Domagała 2011: 81). Na szczęście w ostatnim czasie na rynku pojawia się coraz więcej pozycji ambitnych, wysmakowanych plastycznie, oferujących zróżnicowaną szatę graficzną i mądrze napisane historie. Jest to w dużej mierze wynikiem mrówczej pracy (nie tylko na polu stricte wydawniczym) kilkunastu podmiotów zwanych dziś powszechnie „liliputami” (por. Paprocka, Biernacka-Licznar 2016).

Niniejszy artykuł ma na celu przyjrzenie się przekładowi książki obrazkowej dla dzieci, który z co najmniej kilku powodów wydaje się wyzwaniem wyjątkowym. Lista zagadnień specyficznych dla tego gatunku zostanie wsparta przykładami z tłumaczonych na język polski ${ }^{1}$ pozycji francuskojęzycznych wydanych w ostatnim dziesięcioleciu przez wspomniane powyżej wydawnictwa lilipucie. Dla ułatwienia lektury skorzystam z pewnego uproszczenia terminologii: twórcy warstwy tekstowej określani będą autorami, a odpowiedzialni za warstwę wizualną - ilustratorami.

${ }^{1}$ Autor artykułu jest zawodowym thumaczem literackim, a część przytaczanych przykładów pochodzi z przełożonych przez niego książek. 


\section{Książka czy obrazkowa?}

Już sam polski termin „książka obrazkowa” jest źródłem wielu kontrowersji o podłożu zarówno leksykalnym, jak i genologicznym, o czym pisała między innymi Małgorzata Cackowska, uznając to określenie gatunkowe za „niefortunne”: poprawne gramatycznie, ale kłopotliwe pod względem semantyki (Cackowska 2009-2010). Wspomina o tym także Krystyna Zabawa, która podkreśla nieprecyzyjność pojęcia i jego nieprzystawalność do dzisiejszej oferty (Zabawa 2013: 78). Wydaje się, że problem ma swoje źródło głównie w protekcjonalnym podejściu zarówno literaturoznawców, jak i historyków sztuki do tego gatunkowego mieszańca, co przyczyniło się do jego mocno zredukowanej obecności w branżowych słownikach (zauważonej przez obydwie wspomnianej powyżej badaczki), a co za tym idzie - do terminologicznego zamętu.

Rozbieżności w postrzeganiu tego polisemiotycznego gatunku wynikają najczęściej z potrzeby mniej lub bardziej precyzyjnego określenia (nazwania, zidentyfikowania) relacji między warstwą tekstową i wizualną. Na przykład cytowana przez Cackowską amerykańska badaczka Barbara Bader w swojej definicji książki obrazkowej (picturebook) określa ją jako „całościowy projekt” zależny od ,współbrzmienia obrazów i słów”, podobnie jak Lawrence R. Sipe, który definiuje relację między tekstem i grafiką jako synergiczną. Z kolei Maria Nikolajeva i Carole Scott wskazują raczej na komunikację książki obrazkowej z czytelnikiem przez dwie oddzielne sieci znaków, pomiędzy którymi zachodzą liczne interakcje. Są wreszcie zwolennicy dominacji jednej z warstw, na przykład Uri Shulevitz i Kenneth Marantz, którzy uznają obraz za warstwę nadrzędną (2009-2010). Mazepa-Domagała rozpisuje wspomniane powyżej współistnienie tekstu i grafiki na trzy zasadnicze kompozycje, uwzględniając potencjalną dominację jednej z warstw: a) grafika przedstawia to, czego tekst nie może wyrazić; b) grafika przedstawia to, o czym mowa w tekście; c) grafika wnosi własne wartości, ale to tekst zachowuje rolę dominującą (Mazepa-Domagała 2011: 81). Riitta Oittinen dodaje tu jeszcze perspektywę narracyjną, zaznaczając śladem Davida Lewisa, że książki obrazkowe (picture books) swoją historię mogą opowiadać czasem tekstem, a czasem grafiką (Oittinen 2003: 131).

Zróżnicowane relacje tekstu i grafiki w książce obrazkowej zapewne bardziej wymownie oddaje przewijający się powyżej anglojęzyczny termin, którego różne formy zapisu (picture-book, picture book, picturebook) miałyby umożliwiać wyraźne zarysowanie kilku równorzędnych podgatunków 
(Cackowska 2009-2010). Również on jednak, z racji swojej obcojęzycznej proweniencji oraz uwikłania w nieco sztuczny medialno-marketingowy szum, wciąż budzi wątpliwości i kontrowersje (por. Szyłak 2014).

Zasadniczo jednak różnorakie przytaczane powyżej definicje i terminy wydają się zgodne co do symbiotycznego funkcjonowania warstwy tekstowej i wizualnej w jednym dziele, określonym mianem tekstu kulturowego (Cackowska 2009-2010). Dlatego też w niniejszym artykule przyjmę roboczo pojęcie „książka obrazkowa”, mając pełną świadomość niedostatków tego terminu. $Z$ przekładoznawczej perspektywy kluczowe jest bowiem nie tyle wyraźne zdefiniowanie relacji między grafiką i tekstem (dominacja, współbrzmienie, interakcja), ile sam fakt ich współistnienia w jednym zamkniętym utworze, za którego przekład tłumacz odpowiada całościowo, nie mając jednocześnie pełnej kontroli nad częścią komunikatu.

Ponadto omawiane zjawisko zilustrowane zostanie przykładami z książek o różnych koncepcjach artystycznych, pojawią się wśród nich bowiem dzieła, w których główny ciężar narracji opiera się na warstwie wizualnej, a tekst tylko dopowiada i ułatwia jej zrozumienie (dominacja grafiki), oraz takie, w których elementy tekstowe i wizualne dopełniają się nawzajem, komentują, odkrywają nowe sensy wpisane w szarady językowo-graficzne (interakcja), a wreszcie także utwory, w których warstwa wizualna, dominująca nad tekstem fizycznie (objętościowo), stanowi jedynie ilustrację do opowiadanej w nim historii, nie modyfikując w żaden sposób znaczenia słów.

Choć wspomniane powyżej przykłady zaczerpnięte zostały wyłącznie z literatury dziecięcej, samo zjawisko gatunkowe książki obrazkowej nie ogranicza się rzecz jasna do tego grona odbiorców. Podobnie jak książka obrazkowa nie musi być adresowana (tylko) do dzieci, tak i literatura dziecięca nie musi koniecznie wpisywać się w różnorakie definicje książki obrazkowej.

Ograniczenie wyboru konkretnych przykładów-przekładów akurat do sektora książki obrazkowej dla dzieci podyktowane było wyjątkowym stopniem trudności wynikającym ze specyfiki tych publikacji. Nie tylko bowiem tekstowi towarzyszy tu warstwa wizualna, ale też, jak wspomina Oittinen w swojej klasycznej już pozycji Translating for Children, książki te są przeznaczone do głośnego (w przypadku dzieci nieczytających samodzielnie), a przede wszystkim wspólnego czytania (por. Oittinen 2000: 4-5).

Wydaje się, że zarówno przekład książek obrazkowych (bez wskazania kategorii wiekowej odbiorcy), jak i przekład literatury dziecięcej (niekoniecznie wzbogaconej o warstwę wizualną) same w sobie stanowią już 
oddzielne i specyficzne zjawiska przekładowe. Połączenie tych dwóch aspektów: grafiki towarzyszącej tekstowi oraz dorosłego towarzyszącego dziecku w lekturze, w jednym „,tekście kulturowym” stawia tłumacza książek obrazkowych dla dzieci w położeniu podwójnie nietypowym i dezorientującym, żeby nie powiedzieć po prostu: niewygodnym. Tłumacz taki może z pewną zazdrością spoglądać na ogromną swobodę pracy z tekstem przypisywaną przez Zohar Shavit tłumaczowi literatury dziecięcej (w przeciwieństwie do thumacza literatury skierowanej do dorosłego czytelnika) - swobodę wynikającą z peryferyjnej pozycji tej literatury w polisystemie literackim, która miałaby mu pozwalać na szeroko zakrojone zmiany w tekście podyktowane dopasowaniem się do zastanych w kulturze docelowej konwencji (Shavit 1986: 112). Jak łatwo sobie wyobrazić, w przypadku książki obrazkowej wspomniana swoboda zostaje w znacznej mierze ograniczona przez towarzystwo warstwy wizualnej.

Ta po wielokroć specyficzna pozycja tłumacza w procesie tłumaczenia zostanie szerzej omówiona w ramach zaproponowanej koncepcji przekładu towarzyszącego.

\section{Przekład towarzyszący}

Kiedy sprowadzimy komunikację literacką do najprostszego możliwego schematu: autor - komunikat - odbiorca, pozycja tłumacza oraz zakres jego kompetencji wydają się w miarę klarowne. Dzięki doskonałej znajomości języka źródłowego (właściwego autorowi) tłumacz umożliwia odbiorcy zapoznanie się z komunikatem w języku docelowym. Proces ten można oczywiście badać z wielu perspektyw, chociażby socjologiczno-kulturowej (wpływ środowiska tłumacza na jego pracę) czy edytorskiej (wpływ redaktorów na ostateczny kształt przekładu), jednak postacią centralną przekładu, rozumianego jako pośredniczenie między nadawcą i odbiorcą, pozostanie tłumacz, a punktem odniesienia w procesie wydawniczym - wykonany przez niego przekład.

Tymczasem w przypadku książki obrazkowej dla dzieci dominująca pozycja tłumacza zostaje osłabiona przez wzbogacenie schematu komunikacyjnego o nowe elementy. Do autora tekstu dołącza grafik (nawet jeśli czasem to ta sama osoba), komunikat zyskuje warstwę wizualną, a odbiorca prymarny (dziecko) najczęściej przyswaja werbalną część komunikatu za pośrednictwem odbiorcy sekundarnego (czytającego dorosłego). 
Zarysowane powyżej nagłe zagęszczenie to główna cecha charakterystyczna przekładu, który można by określić mianem towarzyszącego. Termin ten wskazywałby nie tylko na stałą obecność grafiki nieodłącznie towarzyszącej tekstowi, lecz także na nowych uczestników procesu wydawniczego, którzy towarzyszą tłumaczowi przy pracy nad książką obrazkową dla dzieci. Ich obecność, choć często bywa źródłem dodatkowych komplikacji, może stanowić ciekawą odmianę i wnosić do tej zazwyczaj samotniczej pracy pewien akcent społeczny.

\section{Nadawca}

Kim jest w tym schemacie nadawca? Zacznijmy od tego, że najczęściej jest to para twórców, z których jeden odpowiada za grafikę, a drugi za tekst. Można zakładać, że również między owymi twórcami toczy się pewna gra o dominację nad komunikatem, w której jednak autor tekstu, w pewnym sensie bliższy thumaczowi, stoi na z góry przegranej pozycji. Wynika to ze specyficznej dla wieku dziecięcego percepcji - w przypadku przeznaczonej dla najmłodszych książki obrazkowej przekaz wizualny zawsze dociera do odbiorcy szybciej i w bardziej syntetycznej formie niż przekaz językowy o podobnym ładunku emocjonalnym (por. Mazepa-Domagała 2011: 74, Zając 2000: 22-23).

W wyniku splotu kodu werbalnego i ikonicznego kodu semantycznego, reprezentowanego przez obrazy i ilustracje, powstaje twór zwany ikonotekstem. Pojęcie to, w definicji Kirstin Hallberg przytaczanej przez Cackowską, zakłada niepodzielną jedność słowa i obrazu, które dopiero razem uruchamiają swój właściwy przekaz (2009-2010). Wspomniana już Zabawa proponuje nawet, żeby w obliczu terminologicznych niedostatków określenie „książka obrazkowa” zastąpić określeniem „książka ikonotekstowa” (2013: 78). Warto tu od razu zaznaczyć za Szyłakiem, że samo pojęcie ikonotekstu funkcjonowało już wcześniej w dyskursie naukowym, chociażby w badaniach Petera Wagnera czy Asy Briggsa i Petera Burke'a (Szyłak 2014: 18-19). Ikonotekst w ujęciu Wagnera ma bardziej charakter retoryczny niż formalny i służy „,skonstruowaniu wypowiedzi, w której chodzi o transmisję treści przekazywanej za pomocą dwóch rodzajów znaków, dopełniających się nawzajem" (Szyłak 2014).

Jakkolwiek by definiować ten termin, skonfrontowany z ikonotekstem thumacz zostaje zmuszony do wkroczenia na nowe pole działalności: jako „zawodowy czytelnik” musi być w stanie w profesjonalny sposób odczytać 
warstwę graficzną tłumaczonej książki (por. Oittinen 2003: 139). Jest to warunek niezbędny nie tylko do dogłębnej analizy i interpretacji oryginału, bez których nie można rozpocząć pracy nad przekładem, ale także do osiągnięcia na koniec pracy pokojowego współistnienia w jednym dziele warstwy przetworzonej (przełożony tekst) z warstwą oryginalną (grafika). Stosując definicję zaproponowaną przez Hallberg, Oittinen wyraźnie zaznacza, że ikonotekst po przejściu przez proces przekładu zawiera w sobie nie tylko narracje autora i ilustratora, lecz także tłumacza (Oittinen 2003: 132-134).

\section{Komunikat}

Podstawowym punktem odniesienia dla tłumacza książki obrazkowej dla dzieci, a w zasadzie książki dla dzieci jako takiej, zawsze będzie jej performatywne przeznaczenie. Nakłada ono bowiem na tłumacza obowiązek zadbania o to, by czytanie tekstu na głos było jak najprostsze (Oittinen 2003: 132). A zatem - niezależnie od warstwy wizualnej i jej relacji z oryginalnym tekstem - kluczowym zadaniem na poziomie mikro będzie suflowanie czytającemu dorosłemu tekstu wyposażonego w środki poetyckie ułatwiające głośne czytanie - przybierające postać chociażby instrumentacji głoskowej, powtórzeń i rytmicznej składni.

Dodajmy, że z powodów marketingowych książkom dziecięcym bardzo często przypisuje się odgórnie konkretne grupy odbiorców według kryteriów wieku. Tej klasyfikującej oceny dokonuje oczywiście wydawca, a dla tłumacza ma ona stanowić wskazówkę w kwestii chociażby doboru słownictwa czy długości zdań.

Następnie nadchodzi pora na szersze spojrzenie i kreatywną pracę na poziome makro, z uwzględnieniem nie tylko bogatej i zróżnicowanej relacji obraz - tekst, ale też koncepcji konstrukcyjnej całej książki, a nawet kontekstu rynkowego (profil wydawnictwa, seria wydawnicza) bądź kulturowego (zawarta w języku obyczajowość).

\section{Odbiorca}

Zmagania związane z wielopostaciowym, synkretycznym komunikatem to nie koniec osobliwości analizowanego tu procesu komunikacji. Wiemy już, że nadawców może być kilku, a złożony z dwóch warstw komunikat może 
stymulować różne zmysły odbiorcy niezależnie od siebie. Kim jednak jest sam odbiorca? I dlaczego znów nie jest to jedna osoba?

Oittinen stawia sprawę jasno, choć nieco sentencjonalnie: skoro pisanie książek dla dzieci jest pisaniem dla dzieci, to tłumaczenie takich pozycji będzie thumaczeniem dla dzieci (Oittinen 2003: 128). Stwierdzenie to jest do pewnego stopnia słuszne na poziomie intencji - książki dziecięce są oczywiście pisane, a w przypadku książek obrazkowych również rysowane, w pierwszej kolejności dla dzieci - odbiorców docelowych i prymarnych. Choć już na przykład Shavit zaznacza wyraźnie, że większość pisarzy próbuje mimo wszystko adresować swój tekst do obu grup odbiorców jednocześnie (co nie wyklucza dwóch alternatywnych opcji: zwracania się autora bezpośrednio do dziecięcego czytelnika przy „odrzuceniu” dorosłego oraz zwracania się autora bezpośrednio do rodzica, kiedy dziecko ze [współ] odbiorcy staje się zaledwie pretekstem) (Shavit 1986: 63). Również Zabawa wskazuje wyraźnie na dominującą dziś w literaturze dziecięcej wieloadresowość, stwierdzając, że „,coraz rzadziej kieruje się ją [literaturę dziecięcą] tylko do dziecka" (2013: 92). Trudno więc nie wspomnieć w tym kontekście o sekundarnym odbiorcy komunikatu, czyli czytającym dorosłym - osobie, której ,proces wykształcenia kompetencji do uczestnictwa w kulturze jest zakończony (lub mocno zaawansowany)" (Zając 2000: 157-158).

Zresztą nawet gdybyśmy chcieli oderwać się od ingerującego w proces komunikacji dorosłego i zwrócić się bezpośrednio do dziecka, ostatecznie i tak skonfrontujemy się z wymogiem wyobrażenia go sobie jako modelowego odbiorcy i określenia cech jego odbioru. Będzie to zadaniem mocno subiektywnym, gdyż, jak powtarza Oittinen za Lefevere'em, thumacze podlegają w tym kontekście silnym wpływom swojego obrazu dziecka, a także norm dominujących w społeczeństwie (por. Oittinen 2003: 129, Królak 2017). Jeżeli więc zakładać, że tłumacz w toku pracy zawsze tworzy sobie roboczy obraz potencjalnego odbiorcy, to w przypadku książki obrazkowej dla dzieci w procesie tym pojawi się kilka dodatkowych niewiadomych. Tłumacz musi się liczyć z obecnością dwóch grup odbiorców, między którymi na jednym poziomie jest widoczna wyraźna hierarchia (dorosły osobiście przetwarza komunikat werbalny w wyniku głośnej lektury), na drugim jednak odbiór odbywa się samodzielnie (dziecko niezależnie odbiera czy też chłonie warstwę graficzną).

Jak wynika z powyższej analizy, książka obrazkowa jako spleciony z wielu nici komunikat bynajmniej nie trafia do odbiorcy (odbiorców) w jednolitej formie. Na pewnym etapie odbioru zostaje bowiem z powrotem rozplątana na 
drobne pasemka, które docierają do celu niezależnie od siebie. Nietrudno się domyślić, że thumacz w tym złożonym procesie nadawczo-odbiorczym może się czuć zdezorientowany. W dodatku, próbując jak najpełniej uwzględnić wzajemne relacje grafiki i tekstu, łatwo może popaść w nadinterpretację albo przeciwnie - zaniedbać ważne detale, co w obydwu przypadkach prowadzi do nieintencjonalnego i niepożądanego braku spójności przekładu (por. Oittinen 2003: 139). Tak czy inaczej, warstwa wizualna jest tu immanentnym elementem procesu thumaczenia - parafrazując znane piłkarskie powiedzenie, można by stwierdzić, że tłumacz przekłada tak, jak mu grafika pozwala.

Warto tutaj wspomnieć słowa Oittien, która głosi, że tłumacząc książki obrazkowe, tłumaczy się całość: część słowną i wizualną. Wspomniane przez nią ,ttumaczenie całości” dotyczy jednak bardziej procesu tłumaczenia (translacji), przy którym tłumacz powinien uwzględnić warstwę wizualną dzieła, niż samego efektu finalnego pracy tłumacza (translatu). Ten bowiem, zestawiony z grafiką w przekładzie-produkcie wydawniczym, zawsze będzie tylko elementem większej całości.

W kolejnej części artykułu prześledzimy na kilku przykładach, z jakimi konkretnie wyzwaniami i ograniczeniami wiąże się opisane powyżej zjawisko przekładu towarzyszącego.

\section{Brzmienie tekstu - wymowa ilustracji}

Liczne przykłady analogii między elementami plastycznymi i komunikatem werbalnym można znaleźć w książce Przed twoim urodzeniem (Bien avant toi) duetu Rascal i Mandana Sadat. Narratorem opowieści jest ojciec, który opowiada dziecku o tym, jak przed poznaniem jego matki próbował sam stworzyć sobie „ludzika”, którym mógłby się opiekować - nie udawało mu się to jednak z różnych powodów. Chociaż na poziomie fabularnym ludziki kończą zawsze tragicznie (ludzik z chleba został rozdziobany przez ptaki, ludzika z piasku zmyło morze, ludzika z kamyków porwał strumień itd.), to jednak ilustracja na przemian pogłębia i łagodzi smutek płynący ze słów narratora. Powstaje w wyniku tego bardzo subtelna słodko-gorzka historia, a cała koncepcja odbija się również w warstwie poetyckiej języka narracji.

Na jednej z plansz zrobiony z łakoci mały rycerz walczy ze smokiem, czemu towarzyszy w oryginale zdanie J'ai fait un petit bonhomme en bonbons et biscuits / et le gourmand l'a devoré. W pierwszej części zdania od razu wpada w oko (bądź ucho) rytmiczna aliteracja, w drugim natomiast 
poza podobnym zabiegiem (le - l'a) uwagę zwraca nagromadzenie spółgłosek dźwięcznych, warczących i zwarto-wybuchowych, co w wymowie powinno wywołać odrzucający efekt - ostatecznie słowa te określają smoka, który za chwilę pożre ludzika. Ma to zapewne na celu stylistyczne (pejoratywne) doprecyzowanie tej postaci, gdyż oszczędna ilustracja przestawia jedynie dość neutralny zarys stwora. Tym razem zatem ilustracja raczej podkreśla tragizm sytuacji: widoczny na skraju planszy uśmiechnięty autor ludzika pochłania słodycze z zamkniętymi oczami, podczas gdy stworzony przez niego rycerzyk toczy nierówną i z góry przegraną walkę z potworem.

W przekładzie zachowano pierwszą aliterację, proponując w zasadzie dosłowne thumaczenie: „Zrobiłem ludzika z cukierków i ciastek”. Drugi człon zdania natomiast - ,ale zjadł go wielki łakomczuch” - odbiega już stylistycznie od oryginału, postawiono bowiem na łagodne w brzmieniu spółgłoski szczelinowe i półotwarte oraz dużo większy udział spółgłosek bezdźwięcznych. W dodatku o ile ekwiwalencja pary gourmand - „,akomczuch" nie podlega dyskusji, o tyle już czasownik dévorer, szczególnie zastosowany do zwierząt, to raczej „pożerać” niż ,jeść”. W ten sposób w wyniku kilku - wydawałoby się - drobnych decyzji zmieniono tonację całej sceny na łagodną, niemalże żartobliwą.

\section{Metaforyka ilustracji - frazeologia tekstu}

W przytoczonym powyżej przykładzie tekst towarzyszący ilustracji miał decydujący wpływ na wywoływany przez nią nastrój, a zatem przekład oddziaływał znacząco na odbiór warstwy graficznej. Trafiają się także powiązania działające w nieco inny sposób: określone elementy graficzne mają swoje odpowiedniki w poetyce tekstu, lecz już nie na poziomie fonetyki, ale raczej pola leksykalnego czy frazeologii. Ich dostrzeżenie bądź pominięcie w przekładzie nie zmienia co prawda wymowy ilustracji, ale wpływa na spójność ikonotekstu.

Zjawisko to można zaobserwować szczególnie w przypadku bogatych plastycznie, nasyconych symboliką ilustracji, czego dowód znajdziemy w książce Szczęśliwi rodzice (Les heureux parents) napisanej przez Laëtitię Bourget i zilustrowanej przez Emmanuelle Houdart. Książka ta opowiada w baśniowej konwencji o rodzicielstwie Księcia i Księżniczki, przedstawiając w kolejnych scenach ich przeżycia od chwili poczęcia pierwszego dziecka aż do momentu zostania dziadkami. 
Na jednej z plansz świeżo upieczeni rodzice leżą razem z dzieckiem w łóżku o kształcie serca, a przykrywającą ich kołdrę pokrywa sieć czerwonych linii przypominająca schemat tętnic w układzie krwionośnym. Podpis Quand le manque de sommeil creusait leur yeux fatigués (dosł. „,kiedy brak snu drążył linie pod ich oczami”) został przetłumaczony zgodnie z polskim ekwiwalentem jako: ,że z powodu braku snu wokół ich zmęczonych oczu pojawią się głębokie cienie".

Mamy tu jednak problem tłumaczeniowy wynikający z różnego obrazowania: to samo zjawisko (worki pod oczami) w języku francuskim opisuje się, podkreślając linię pojawiającą się pod okiem, a w polskim - skupiając na zmianie odcienia skóry. Tymczasem wydaje się, że w cytowanej powyżej scenie czasownik creuser (dosł. „żłobić, drążyć, kopać”) nawiązuje do wspominanej sieci tętnic rozchodzących się po całej kołdrze, przecinających jej powierzchnię. Nawiązanie to zgubiło się w przekładzie ze względu na wybór takiego, a nie innego wyrażenia frazeologicznego.

Motywy cielesne i anatomiczne należą zresztą do charakterystycznego stylu ilustratorki, a ten sam motyw tętnic powraca kilka plansz dalej, kiedy widzimy księżniczkę trzymającą na rękach już dwoje dzieci. Dolną część jej tułowia skrywa pofałdowany materiał sukni znów naznaczony siecią czerwonych tętnic, ale w bardziej nasyconym kolorze oraz o większym zagęszczeniu, podkreślającym zwiększoną intensywność życia związaną z pojawieniem się drugiego potomka.

Wspomniana intensywność zostaje również wyraźnie zaznaczona w towarzyszącym ilustracji zdaniu poprzez zastosowanie powtórzenia: Quand la princesse devait donner des câlins toujours plus longs et plus doux (dosł. „Kiedy księżniczka musiała obdarzać dzieci wciąż coraz dłuższymi i coraz czulszymi pieszczotami”). Powstałe w ten sposób nawiązanie gubi się niestety w przekładzie - ,że księżniczka nie będzie mogła ani na chwilę przerwać czułych pieszczot" - gdyż w wyniku zastosowania transpozycji zrezygnowano z powtórzenia składniowego.

\section{Semantyka obrazu - frazeologia tekstu}

Przytoczone powyżej przykłady nie świadczą bynajmniej o tym, że tłumaczowi pracuje się tym trudniej, im bardziej wyrafinowana jest warstwa graficzna przekładanej książki. Prawdziwe wyzwanie mogą stanowić również bardzo skromne plastycznie pozycje, czego dobrym przykładem będzie 
plansza z Miłości (Mon amour) Astrides Desbordes i Pauline Martin. Tym razem to nie warstwa słowna modyfikuje wymowę ilustracji; wręcz przeciwnie - w wyniku frazeologicznej szarady ta sama treść słowna w towarzystwie dwóch różnych ilustracji zyskuje inne, niemalże przeciwstawne znaczenie.

Na pierwszym rysunku mały Archibald przytula się do mamy, która zza kadru dodaje Je t'aime quand tu es contre moi (dosł. „kocham cię, kiedy się do mnie przytulasz"). Na sąsiadującej stronie widzimy scenę konfliktu matki z synem, której towarzyszy podpis niemalże tej samej treści - et quand tu es contre moi - wprowadzony spójnikiem współrzędnym et (pol. „i”). Zastosowana tu gra językowa polega na wieloznaczności francuskiego przysłówka contre, który poza najczęstszym zastosowaniem w znaczeniu „przeciwko”, „wbrew”, bywa także używany w wyrażeniach frazeologicznych typu s'appuyer contre qq'un (,oprzeć się o kogoś”), se serrer contre qq'un (,przytulić się do kogoś”). Drugie zdanie nabiera całkiem nowego, diametralnie innego znaczenia dopiero zestawione z ilustracją.

Zobrazowana tu dychotomia czułość - konflikt, zawierająca w sobie całe zróżnicowanie miłości macierzyńskiej, jest niemożliwa do oddania w języku polskim poprzez zastosowanie prostego ekwiwalentu. Nie pozwalają na to różnice frazeologiczne między dwoma językami. W przekładzie - „Kocham cię, kiedy jesteś blisko”, ,, kiedy blisko jest awantura” - udało się zachować powtórzenie, choć ograniczono je do jednego słowa. Wymagało to znacznej modyfikacji drugiego zdania, a także wprowadzenia do intymnej relacji między matką i dzieckiem trzeciego podmiotu (,awantura”), co wydaje się zaledwie kompromisowym wyjściem z sytuacji.

\section{Obraz w tekście - tekst w obrazie}

Relacje między tekstem i ilustracją nie muszą zresztą przybierać postaci skomplikowanych aluzji ani ukrywać się głęboko na poziomie poetyki, żeby zmusić tłumacza do rezygnacji z dosłownego podążania za pomysłem autora. Czasami w odtwarzaniu oryginalnych zabiegów stylistycznych w języku docelowym przeszkadzają tak banalne zjawiska jak choćby antroponimy czy morfologia.

W jednej z miniscenek składających się na szaloną, purnonsensową książkę Delphine Durand Mój dom (Ma maison) pewna zamaskowana postać spotyka drugą, której owalny, cylindryczny tułów, przypominający kiełbasę, jest oznaczony literą „B”. Pada wówczas pytanie: C'est toi Antonin le 
Boudin? („Czy to ty jesteś Antoni Kiszka?”), przy czym oryginalne słowo le boudin (,kiszka”) nawiązuje do litery „B” na tułowiu nieznajomego (aluzja ta gubi się w przekładzie). Oryginalna odpowiedź Moi, c'est Bérénice la Saucisse, przełożona niemalże dosłownie jako „Jestem Berenika Kiełbaska”, wyjaśnia obecność litery „B” na tułowiu postaci, ale tym razem z kolei zgubił się dodający komizmu rym („Berenice la saucisse”, analogicznie do rymu w „Antonin le boudin”, którego również nie udało się oddać).

Bywają zatem sytuacje, gdy nagromadzenie zabiegów stylistycznych (rym imienia Antonin i przydomka boudin i powtórzenie pierwszej litery przydomka na początku imienia drugiej postaci - Bérénice la saucisse - przy jednoczesnym zachowaniu rymu również w tej parze imienia i przydomka), których wzajemne relacje przypieczętowuje element graficzny, składa się na sieć powiązań niemal niemożliwą do pełnego odtworzenia. Kiedy do językowej łamigłówki dołącza element ilustracji, tłumacz zostaje pozbawiony możliwości rozwikłania jej samodzielnie, gdyż każda potencjalna ingerencja w ilustrację naruszająca jej integralność wymaga nie tylko zgody ze strony ilustratora, lecz także czynnego udziału grafika.

Przykład ten przypomina nam o zasygnalizowanej już wcześniej specyfice przekładu towarzyszącego - to nie tylko praca nad tekstem, któremu towarzyszy ilustracja, lecz także udział w szerszym procesie, w którym decyzje tłumacza mogą czasem zapadać w „towarzystwie”, a właściwie przy czynnym udziale innych aktorów procesu wydawniczego.

\section{Frazeologia przekładu - metaforyka obrazu}

Obecność grafiki nie zawsze jednak musi być dla tłumacza dodatkowym obciążeniem czy przeszkodą. Czasami może dość nieoczekiwanie wpasować się w strukturę języka docelowego czy wręcz sprowokować zastosowanie w przekładzie elementów stylistycznych, których brak w oryginalnym tekście.

Występowanie takiego zjawiska sugeruje pojedynczy kadr z książki Serge'a Blocha Wielka historia małej kreski (La grande historie d'un petit trait). Jej bohater, mały chłopiec, znajduje kawałek czerwonej kreski, która następnie towarzyszy mu przez długi okres życia, przybierając w kolejnych kadrach różne kształty. Na jednej z pierwszych plansz kreska, zmęczona zabawą z bohaterem, zwija się w spiralny kształt i zasypia. Bohater opowiada to całkowicie neutralnym, opisowym językiem: il s'est enroulé (,zwinęła 
się") et il s'est endormi (,,i zasnęła”). W języku polskim aż prosi się w takim momencie o użycie wyrażenia ,zwinąć się w kłębek”, z czego tłumacz skorzystał. Dzięki temu drobnemu frazeologizmowi dość surowy graficznie kawałek czerwonej kreski zyskał w przekładzie cieplejszy niuans poprzez nawiązanie do kłębka wełny.

\section{Decyzje globalne}

Opisane dotychczas przykłady dotyczyły autorskich wyborów tłumacza podejmowanych w konfrontacji z konkretnymi zagadnieniami językowymi. Tymczasem praca nad przekładem książki obrazkowej pociąga za sobą również szereg decyzji na poziomie całego dzieła. Należy do nich między innymi wybór między egzotyzacją a adaptacją elementów kulturowych, znany chociażby z przekładów literatury pięknej.

W przypadku literatury dla dziecięcego odbiorcy rozwiązaniem bardziej pożądanym będzie zapewne proces adaptacji, znacznie ułatwiający wprowadzanie czytelnika przekładu w świat opisywany w oryginale.

Taki też efekt starano się osiągnąć w tłumaczeniu książki Tuli-pucho-kłaczek (Le merveilleux dodu-velu-petit) Beatrice Alemagni, w której główna bohaterka, Edith (dla przyjaciół Eddie), przemieszcza się w kameralnej przestrzeni małego miasteczka w poszukiwaniu tytułowego stworka, w czym pomagają jej między innymi piekarz Jean, kwiaciarka Wendy oraz antykwariusz Emmett.

Aby przybliżyć dziecięcemu czytelnikowi bohaterów drugoplanowych, a także ułatwić stworzenie intymnej więzi z główną bohaterką, tłumacz zdecydował się na adaptację imion na Edzię, Jana, Różę i Edwarda. Wybór ten został zaakceptowany przez wydawcę, który jednak zaproponował w następstwie również przetłumaczenie części szyldów miasteczkowych sklepów i zakładów, w oryginalnym dziele stanowiących raczej element grafiki niż warstwy tekstowej. W ten sposób początkowy wybór tłumacza, dokonany całkowicie na poziomie tekstu i w oderwaniu od warstwy wizualnej, ostatecznie wpłynął na kształt pewnych elementów graficznych, pociągając za sobą dodatkową pracę zarówno na etapie redakcji książki (decyzja o tłumaczeniu szyldów), jak i jej produkcji (przerabianie oryginalnej ilustracji przez polskiego grafika).

A zatem zależnie od decyzji osób zaangażowanych w produkcję danej książki pewne elementy werbalne wplecione w oryginale w grafikę mogą 
w przekładzie zostać potraktowane albo jako tekst, albo jako element ilustracji. Przeciwieństwem opisanej powyżej sytuacji może być chociażby onomatopeja z książki Misiowa piosenka (Une chanson d'ours) Benjamina Chauda. W jednej ze scen główny bohater książki - tata miś goniący swojego syna niedźwiadka po budynku paryskiej opery - wpada na scenę i wydaje z siebie ryk Graaaaaur. Pokazana na rysunku onomatopeja jest jednocześnie elementem tekstowym i graficznym, ponieważ szereg liter dobywający się z niedźwiedziej paszczy przewraca stojące na scenie postaci śpiewaków.

Skrajnym przykładem takiego balansowania pewnych elementów między statusem grafiki i tekstu jest w zasadzie cała szata graficzna wspomnianego już Mojego domu Durand. Grafika ta składa się nie tylko z setek rysowanych miniscenek, ale też ogromnej liczby prawdziwych ulotek, opakowań, wizytówek, afiszy czy innych druków (w różnym stopniu zdefragmentowanych), wpasowanych w plansze na zasadzie kolażu, które nie zostały zaadaptowane w przekładzie. Wycinki te dla czytelnika oryginału stanowiły zarówno element grafiki, jak i tekstu, natomiast dla odbiorcy przekładu będą tylko i wyłącznie częścią mozaikowego tła. Egzotyzację w przekładzie może zatem wymuszać zastosowana w oryginale technika plastyczna.

\section{Decyzje jednostkowe}

Wspominaliśmy już wcześniej o autonomii warstwy wizualnej książek obrazkowych, która w przeciwieństwie do towarzyszącego jej tekstu przekracza granice językowe niemalże nienaruszona. Wspomniana autonomia formalna nie zmienia jednak faktu, że ten sam obraz może być różnie interpretowany w zależności od wspólnoty językowej (por. Mazepa-Domagała 2011: 76). Kiedy zaś interpretacja odbywa się w obrębie pola leksykalnego, które w danej kulturze stanowi obszar sporów ideologicznych, nawet dobór pojedynczego ekwiwalentu może mieć szczególną wagę.

Zjawisko to doskonale ilustruje książka Mademoiselle Zazie a-t-elle un zizi autorstwa Thierry'ego Lenaina i Delphine Durand, która doczekała się już w Polsce dwóch wydań (Czy Kasia to chłopak z 1999 oraz Czy Zuza ma siurka z 2013). Głównym bohaterem książki jest Maks, którego chłopięca wizja świata została wystawiona na próbę wraz z pojawieniem się w klasie nowej koleżanki - Zuzy. Zuza wykazuje więcej chłopackich cech niż wszyscy koledzy Maksa razem wzięci. Wyjaśnienie może być tylko jedno - Zuza to dziewczyna z ,siurkiem”. 
Od mniej więcej połowy książki wszystkie działania Maksa zmierzają do jednoznacznego wyjaśnienia tej kwestii. W przeciwieństwie do przewijającego się przez całą książkę „,siurka” (fr. zizi), jego żeński odpowiednik - „cipka” (fr. zézette) pada w tekście tylko raz, na samym końcu, w momencie kulminacyjnym, kiedy Maks otrzymuje wreszcie odpowiedź na tytułowe pytanie.

Jak deklaruje sama wydawczyni, wszystkie najważniejsze osoby zaangażowane $\mathrm{w}$ proces publikacji przekładu, $\mathrm{z}$ tłumaczem i redaktorem na czele, miały pełną świadomość co do wymagań, jakie stawia przed nimi taka konstrukcja książki. Decyzja, aby skorzystać w tym miejscu ze słowa „cipka” - którego przynależność do języka potocznego jest wciąż kontestowana - zapadła jednogłośnie, ale poprzedziły ją między innymi konsultacje wśród osób pracujących na co dzień z dziećmi. Wpływ na tę decyzję miała też wydana kilka lat wcześniej Wielka księga cipek Dana Hojera i Gunilli Kvarnstrom oraz inicjowane w tym czasie feministyczne inicjatywy w rodzaju świętowania Dnia Cipki.

Niezależnie od tego, czy w kluczowym momencie padnie słowo „kuciapka” (1999) czy „,cipka” (2013), kompozycja graficzna książki, a szczególnie kadrowanie ostatnich trzech plansz, uniemożliwia jakiekolwiek uniki lub peryfrazy, zmuszając thumacza do wyboru jednego, konkretnego terminu.

\section{Przekład w towarzystwie}

Zbiorowa praca nad przekładem literackim nie jest niczym nowym, a zrównywanie osoby tłumacza z procesem tłumaczenia wydaje się dziś, w kontekście globalnego obiegu treści kulturowych, całkowicie bezzasadne (por. Buzelin 2006: 142, 2004: 739). Oittinen powołuje się tutaj na Bachtinowską koncepcję dialogiczności, określając przekład książki obrazkowej jako wielogłosową sytuację, w której ilustratorzy, autorzy, thumacze, wydawcy i czytelnicy spotykają się i na siebie wpływają (Oittinen 2003: 129).

Wydaje się więc, że formuła przekładu towarzyszącego jest nieodzowna dla tego gatunku literatury. Wykazane powyżej nagromadzenie aktorów procesu wydawniczego bynajmniej nie musi być dla tłumacza zjawiskiem negatywnym. Wszystko zależy od tego, w jakim odnajdzie się towarzystwie.

Wspomniane na wstępie wydawnictwa ,lilipucie” pod względem udziału ilościowego wciąż stanowią na rynku literatury dziecięcej raczej niszę, bez wątpienia jednak to ich wysmakowana i starannie komponowana oferta jest wyznacznikiem jakości i punktem odniesienia dla całego sektora. Wielu 
wydawców z tej grupy, komentując swoje wybory programowe, wspomina wprost o „misyjnym” aspekcie takiej formy działalności. Niewielka w porównaniu do dużych graczy liczba wydawanych pozycji powoduje, że każda kolejna książka jest dla „liliputa” równie ważna, także z ekonomicznego punktu widzenia, co pociąga za sobą wyjątkowo staranną i drobiazgową pracę nad wszelkimi, nawet najdrobniejszymi elementami publikowanego tytułu.

W wyniku tego tłumacz, który wcześniej został w pewnym sensie zdetronizowany, może niejako w nagrodę liczyć na dodatkową satysfakcję z faktu, że jego pracy poświęca się dużo więcej uwagi, niż to bywa w przypadku przekładu beletrystyki stanowiącej element oferty masowej.

Przekład towarzyszący nie musi być więc dla tłumacza wyłącznie źródłem wspomnianego na wstępie zdezorientowania czy zagubienia. Może również oznaczać nadanie tej zazwyczaj samotniczej (choć nie indywidualnej) pracy nowego, bardziej uspołecznionego charakteru.

\section{Bibliografia}

\section{Literatura podmiotu}

Alemagna B. 2017. Tuli-pucho-klaczek, przeł. P. Łapiński, Warszawa: Wytwórnia. Bloch S. 2015. Wielka historia małej kreski, przeł. K. Skalska, Poznań: Zakamarki. Bourget L., Houdart E. 2013. Szczęśliwi rodzice, wersja pol. D. Hartwich, Wrocław: Format.

Chaud B. 2013. Misiowa piosenka, przeł. J. Jędryas, Warszawa: Dwie Siostry. Desbordes, A., Martin P. 2016. Miłość, przeł. P. Łapiński, Warszawa: Entliczek.

Durand D. 2012. Mój dom, przeł. M. Puszczewicz, Warszawa: Entliczek.

Durand D., Lenain T. 2013. Czy Zuza ma siurka?, przeł. M. Puszczewicz, Warszawa: Entliczek.

1999. Czy Kasia to chłopak?, przeł. J. Waczków, Wrocław: Siedmioróg.

Rascal, Sadat M. 2016. Przed twoim urodzeniem, przeł. P. Małochleb, Kraków: Czerwony Konik.

\section{Literatura przedmiotu}

Buzelin H. 2004. La traductologie, l'ethnographie et la production des connaissances, „Meta: journal des traducteurs / Meta: Translators' Journal” 49, http://id.erudit.org/ iderudit/009778ar. [dostęp: 30 kwietnia 2017].

2006. Independent Publisher in the Networks of Translation, „TTR: traduction, terminologie, rédaction" 19, http://id.erudit.org/iderudit/016663ar [dostęp: 30 kwietnia 2017]. 
Cackowska M. 2009-2010. Czym jest książka obrazkowa? O pojmowaniu książki obrazkowej dla dzieci w Polsce - część I, II i III, „Ryms” 5/2009, 6/2009, 8/2009-2010, http://ryms.pl/artykul_szczegoly/12/czym-jest-ksiazka-obrazkowa-o-pojmowaniu-ksiazki-obrazkowej-dla-dzieci-w-polsce-czesc-i-ii-i-iii.html [dostęp: 30 kwietnia $2017]$.

Królak A. 2017. Agata Królak. Ilustracje nie tylko dla dzieci, rozm. przepr. Jakub Knera, http://noweidzieodmorza.com/9583-agata-krolak-ilustracje-nie-tylko-dla-dzieci [dostęp: 30 kwietnia 2017].

Mazepa-Domagała B. 2011. Upodobania obrazowe dzieci $w$ wieku przedczytelniczym w zakresie ilustracji książkowej, Katowice: Wydawnictwo Uniwersytetu Śląskiego.

Oittinen R. 2003. Where the Wild Things Are: Translating Picture Books, „Meta: journal des traducteurs / Meta: Translators' Journal” 48, http://id.erudit.org/iderudit/006962ar [dostęp: 30 kwietnia 2017].

2000. Translating for Children, London - New York: Garland Publishing.

Paprocka N., Biernacka-Licznar K. 2016. Polscy wydawcy lilipuci jako idea-makers?, „Przekładaniec” 32, s. 135-142.

Shavit Z. 1986. Poetics of Children's Literature, Athens - London: The University of Georgia Press, http://humanities1.tau.ac.il/segel/zshavit/files/2014/03/poetics-of-childrens-literature.pdf [dostęp: 25 stycznia 2018].

Skibińska E. 2008. Kuchnia tłumacza. Studia o polsko-francuskich relacjach przekładowych, Kraków: Universitas.

Szyłak J. 2014. To ptak! To samolot! To ikonotekst! Książa - komiks-- picturebook (medium czy media?), w: I. Kiec, M. Traczyk (red.), Komiks i jego konteksty, Poznań: Fundacja Instytut Kultury Popularnej, s. 11-22.

Szyłak J. 2014. Notatki o książkach obrazkowych, „Zeszyty Komiksowe” 17, http:// www.zeszytykomiksowe.org/zeszytykomiksowe/pdf/nr17_szylak_1.pdf [dostęp: 25 stycznia 2018].

Zabawa K. 2013. Rozpoczęta opowieść. Polska literatura dziecięca po 1989 roku wobec kultury współczesnej, Kraków: Akademia Ignatianum - Wydawnictwo WAM.

Zając M. 2000. Promocja książki dziecięcej: podręcznik akademicki, Warszawa: Wydawnictwo SBP. 